\title{
Study on the effects of green-based plant extracts and water- proofers as anti-corrosion agents for steel-reinforced concrete slabs
}

\author{
Jagadeesh Bhattarai ${ }^{1 *}$, Madan Somai ${ }^{1}$, Nirmal Acharya ${ }^{1}$, Ajaya Giri $^{1}$, Akash Roka ${ }^{1}$, and Nav Raj Phulara $^{1}$ \\ ${ }^{1}$ Central Department of Chemistry, Tribhuvan University, Kirtpur, Kathmandu, Nepal
}

\begin{abstract}
Widespread applications of reinforced concrete structures have been practiced since the $20^{\text {th }}$ century because of their excellent properties despite their early corrosion degradation. For the control of such a problem, a design strategy of corrosion-resistant environments of the reinforced concrete structures is highly desirable for extending of a lifetime. The present research work was focused to investigate the effects of the green plant extract-based inhibitors from Vitex negundo and Catharanthus roseus leaves, and one waterproofing chemical (PtS) for controlling the corrosion susceptibility of concrete rebar using a half-cell potential method following the ASTM C876-91 standard. Both plant extracts have good anti-corrosion properties, and hence could be applied as green concrete additives to increase the corrosion resistance of the steel reinforcing bars. The anti-corrosion performance of the steel rebars in concrete is remarkably higher with the additions of 1000 and 2000 ppm plant extracts than the additions of waterproofing chemicals used, based on the shifting of corrosion potential ( $\phi_{\text {corr. }}$ ) values to a more positive direction than $-126 \mathrm{mV}$ (SCE). The results agreed that both the plant extracts could be promising for the formulation of effective, ecofriendly anti-corrosion additives to delay the corrosion susceptibility of the concrete infrastructures.
\end{abstract}

Keyword. Catharanthus roseus, Green-based inhibitor, Rebar corrosion, Vitex negundo, Waterproofing agent

\section{Introduction}

The use of concrete placed $1^{\text {st }}$ position among other manufactured materials, and it is one of the most widely used construction materials in our world after water [1]. The amount of concrete consumption is estimated to be between 25 and $33 \times 10^{9}$ tons annually [2,3], and will continue to be used as a construction material in the future [4]. In 2016, around 4.7 tons of concrete produced each year per person in the world [3]. The concrete matrixes have high compressive strength but very poor tensile and elasticity strengths [5], and for the reasons of being such concrete properties, it is usually practiced to reinforce different carbon and stainless steel rods in the concrete matrixes to retain enough tensile, elastic including compressive strengths combined with durability. The reaction between concrete matrix comprised of cement, fine sand, and coarse gravel with impurities-free water results in the setting and hardening of the cement paste so that it binds both (coarse gravel and fine sand) aggregates [6].

Chloride-free concrete generally provides excellent corrosion protection properties to the reinforced steel or stainless steel rods, due to the high alkalinity nature of cement paste having 12.5-13.5 $\mathrm{pH}$ [7]. As a result, the formation of a thin, protective diffusion barrier, stable, and tightly adhering thin oxide film (i.e., passive film) starts to appear spontaneously on the surface of the reinforced rebars. Details about the mechanism of the process of being formed such passive films on the surface of reinforced steel in a highly alkaline concrete matrix are discussed elsewhere [8]. However, shortcomings associated with reinforcement concrete infrastructures becoming matters of safety and economic point of view for human beings in recent years by depassivation of such diffusion barrier passive layers, mostly due to the loss of alkalinity of the concrete matrix [9].

Most of the reinforcement concrete infrastructures are porous, and different environmental gases and ions including water molecules (moisture) can penetrate the concrete matrix causing damages and failures, which reduced the life of the materials. The most crucial causes of loss of alkalinity in the concrete are atmospheric carbon dioxide $\left(\mathrm{CO}_{2}\right)$, chloride, or sulfate which shifts the $\mathrm{pH}$ of the concrete pore solution to less alkaline

*Corresponding author: bhattarai_05@yahoo.com,jagadeesh.bhattarai@cdc.tu.edu.np 
around the reinforcing steel, making the concrete infrastructures susceptible to corrosion damages [10,11]. Besides, there are several types of physico-chemical, electrochemical, and biological processes occurring on the reinforced steel (rebar) surface in concrete structures in presence of aggressive environmental factors. They accompanied by reduction of $\mathrm{pH}$ values of the concrete structures below $10[12,13]$, which starts depassivation and initiation of corrosion on the rebar surface leading to the loss of functionality, durability, structural integrity and finally resultant safety risks, and economic losses to human beings [14]. The corrosion products formed on the rebar surfaces reduce the gripping force with the concrete matrix and affect the quality of the whole reinforcing concrete infrastructures [15].

As a further matter, there is a growing appeal for developing different green-based corrosion inhibitors acquired from plant extracts in combating the corrosion of reinforced steel in concrete structures because of the less toxic and biodegradable nature of the extracts [11, 16-20]. Studies reported that the suitability of the N-, S-, and O-containing and $\pi$ electron-rich leaves extracts of Phyllanthus muellerianus [18], Chamaerops humilis L. [20], and Olea europaea [21] acted as an effective anticorrosion agent for reinforcing steel in concrete. The leaf extracts of Davidia involucrate [22], A. djalonensis [23], and Pseudomonas aeruginosa [24] acted as a mixed-type corrosion inhibitor from the electrochemical analysis. They enhance the performance of anticorrosion action on the carbon steel plate in concrete pore solution with the formation of an organic layer to restrain both anodic and cathodic reactions. Corrosion protection efficiencies of leaves extracts of Rosa damascena [25], Vernonia amygdalina [26], and Morinda citrifolia [27] to the rebar in aggressive chloride solution reported about $82 \%, 90 \%$, and $58 \%$, respectively. Mostly due to the presence of high amounts of phytochemical constituents containing heteroatoms, aromatic rings, and $\pi$-electrons, which interact with iron ions resulting in the shielding of the steel bar from corrosion in concrete matrix. Water absorptivity of steelreinforced concrete in the presence of Bambusa arundinacea leaves extract reported $<0.07 \mathrm{~mL} / \mathrm{m}^{2} \mathrm{~s}$ after $2 \mathrm{~h}$, as required by ISAT (initial surface absorption test) standard for low permeability concrete [11].

In this condition, the potency of leaves of Nepal origin two plants (i.e., Catharanthus roseus (synonyms: Vinca rosea) and Vitex negundo) explored the first time for minimizing the corrosion level of the reinforced steel rebars in concrete infrastructures. Although previous works reported the effects of these two plant extracts as good anti-corrosion agents to different metals or alloys in acidic [28-30], neutral [31, 32], and alkaline [33, 34] electrolytes. Likewise, the $C$. roseus extracts acted as a mixed type of inhibitor for mild steel corrosion in an acidic medium due to the formation of an adsorptive film of electrostatic character [29, 33]. Methanol extract of C. roseus leaves acted as an efficient and mixed corrosion inhibitor to the mild steel in $\mathrm{NaCl}$ solutions [31, 32], usually due to the presence of several functional entities like hydroxyl, carbonyl groups, and fused heterocyclic compounds in the $C$. roseus extracts which enhanced the corrosion inhibition action. The corrosion inhibition of carbon steel in $1 \mathrm{M} \mathrm{HCl}$ containing aqueous extract of $V$. negundo leaves has been studied using chemical and electrochemical tests, and the results showed that the best concentration of $800 \mathrm{ppm}$ of plant extract showed about $79 \%$ of the inhibition efficiency [30]. Likewise, the corrosion inhibiting the action of $V$. negundo leaves extracts to $\mathrm{Cu}$ metal was investigated in nitric acid [33] and $\mathrm{Al}$ metal in $1 \mathrm{M} \mathrm{NaOH}$ [34], and the studies concluded that the extract acted as efficient corrosion inhibitors and predominantly cathodic (to $\mathrm{Cu}$ in $\mathrm{HNO}_{3}$ ) and mixed (to $\mathrm{Al}$ in $\mathrm{NaOH}$ ) inhibitor from potentiodynamic polarization tests.

Besides, the methanol extract of $V$. negundo plant leaves proved as an efficient and environmentally friendly corrosion inhibitor to improve the anti-corrosion properties of $\mathrm{Cu}$ and $\mathrm{Al}$ metals with about 83-96\% efficiency in pure biodiesel and its $10 \%$ blend with petro-diesel at room temperature in airtight condition [35]. Moreover, the effects of Nepal origin plant species of Vitex negundo and Catharanthus roseus extracts on mild steel corrosion in different bioethanol fuels studied using corrosion, adsorption isotherm, and potentiodynamic polarization tests. The results revealed that the maximum inhibition efficiency reported about 89-86 and 71-75 \% in $V$. negundo and $C$. roseus leaves, respectively, at $2000 \mathrm{ppm}$ [36]. Many researchers have studied the reasons, control strategies, and techniques for such concrete corrosion calamities recently, though very little research works on the assessment of corrosion degree of some reinforcement concrete infrastructures used in the Kathmandu Valley [37], and Pokhara Valley [38] of Nepal. Notwithstanding, some research works carried out on corrosion phenomena and prevention techniques in Nepal in the last decade [39-47].

In this context, the present work aimed to substantiate the efficacy of methanol extracts of Nepal origin two plants of Vitex negundo, and Catharanthus roseus as a green-based corrosion inhibitor in preventing the steel reinforcement corrosion in concrete slabs using a simple and non-destructive half-cell corrosion potential (HCCP) method following the ASTM standard [48]. In addition, a comparative study investigated to identify the effects of commercially used two waterproofing agents on the corrosion degree of the reinforced concrete slabs in ambient environments. The findings of the present works would render a categorization of solution methods for corrosion protection, maintenance, and repair in Nepal first time.

\section{Materials and methods}

\subsection{Preparation of reinforcement concrete slab}

Ordinary Portland cement 53 grade was used for the preparation of rectangular steel-reinforced concrete slabs having the dimensions of $40 \mathrm{~cm} \times 24 \mathrm{~cm} \times 4 \mathrm{~cm}$ in the laboratory following the ASTM standard [49]. For the purposes, locally available fine river sand, coarse aggregate $(2 \mathrm{~cm} \phi)$ and rust-free steel rod (Premier-500 
with $1.2 \mathrm{~cm} \phi)$ were used after removing the rust using 200, 400, 600, 1000 and 1500 grit numbers sandpapers followed by ultrasonic washing with ethanol to degrease and acetone to dry.

The cement, sand, and gravel were mixed in the ratio of $1: 2: 3$, and then added the distilled water $(0.45 \mathrm{w} / \mathrm{c}$ ratio) without and with 500, 1000, 2000, $4000 \mathrm{ppm}$ of each plant extracts or waterproofing agents were separately used to prepare different sets of the concrete mixture. Two steel rods having $12 \mathrm{~mm}$ diameter $(\phi)$ with $8 \mathrm{~cm}$ spacing between the rods were embedded in the concrete matrix to prepare a reinforcement concrete slab, and one end of each embedded steel rod was left exposed for open circuit corrosion potential (OCCP) measurements, as shown in Fig. 1.

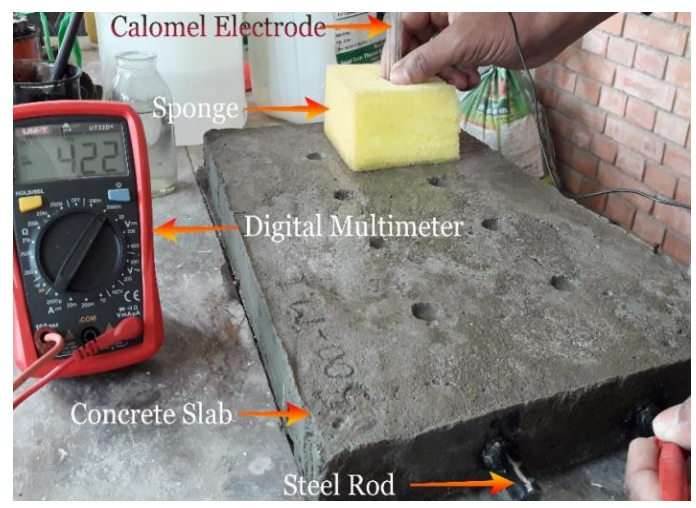

Fig. 1. Set up for the measurement of OCCP.

The OCCP values of each steel bar were recorded on a digital multi-meter (UNI-T Business, Hong Kong) using a saturated calomel electrode (SCE) as a reference, and the exposed steel rod of the concrete slab as working electrodes, as shown in Fig. 1. Eight points, marked as 1, $2,3,4,5,6,7$, and 8 at equidistant from the sides were fixed on the surface of each steel-reinforced concrete slab. The SCE electrode and steel rod were connected to the negative and positive terminals, respectively, of the voltmeter for the record of the OCCP values of all these eight points of each slab after 7 days of the slab preparation up to about 5 months.

\subsection{Preparation of plant extracts}

The leaves of Vitex negundo and Catharanthus roseus plants, as shown in Figs. $2 \mathrm{a}$ and $2 \mathrm{~b}$, respectively, were collected from Pokhara-21 $\left(28.1503^{\circ} \mathrm{N}, 83.9903^{\circ} \mathrm{E}\right)$ of Kaski district, Nepal. They thoroughly washed with distilled water to remove dirt substances attached to the leaves surface, and then shade dried for few weeks until it completely dried to make dry powder (Fig. 2) with the help of an electric grinder. About $200 \mathrm{~g}$ of each pulverized leaves powder was transferred into a corked $500 \mathrm{~mL}$ conical flask containing $400 \mathrm{~mL}$ of methanol (Fig. 2c). The mixture of each separate plant was stirred well and then was kept in a dry dark place for about two weeks. Then the methanol extract of each $V$. negundo and $C$. roseus leaves powder was obtained by the soxhlet extraction using rotavapor (Fig. 2d), dried to obtain solid plant extract and stored at $4^{\circ} \mathrm{C}$, which was added in the concrete matrix as a green-based corrosion inhibitor to the steel-reinforced concrete slabs. For the purpose, the required amount of each solid plant extract mixed with distilled water that was used to prepare the reinforced concrete slabs.

\subsection{Premise of corrosion condition of rebars}

Different corrosion conditions of the reinforcing steel rod (rebar) in concrete slab were established with their recorded OCCP values according to the ASTM standards [48] in the HCCP technique. In this standard method, the probability of the corrosion level of the rebars ascertains with the recorded OCCP values, which is feasible to make a diagnosis of the corrosion level of the rebar in concrete infrastructures [51].

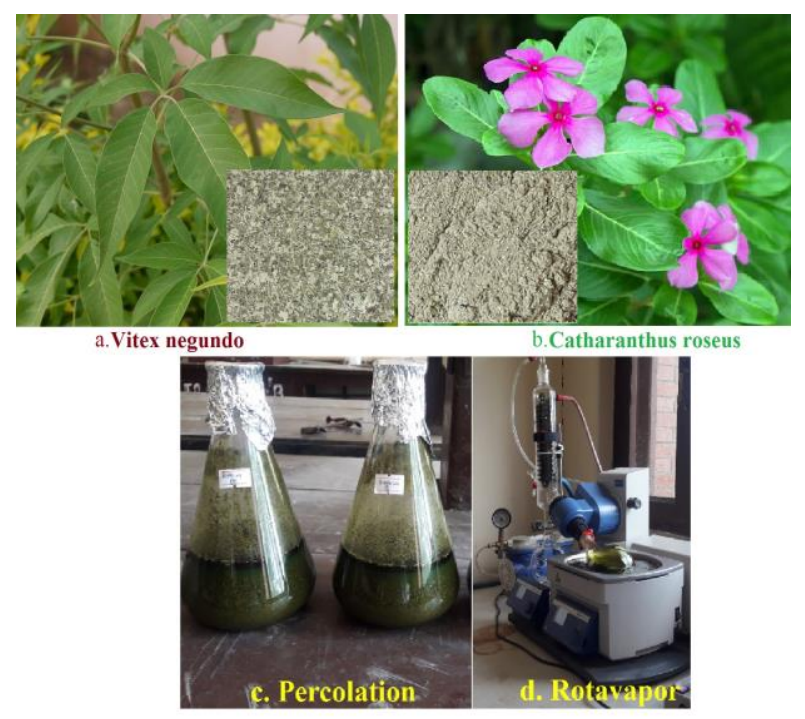

Fig. 2. Preparation processes of the methanol extracts of $V$. negundo and $C$. roseus plant leaves.

The corrosion level of the concrete rebars consider to be low (Lcr) or less than $10 \%$ at the time of measurement if the recorded OCCP values are more positive than $-126 \mathrm{mV}$ vs SCE. Besides, the corrosion level of the reinforced steel in the analyzed concrete structures at the measured areas assumes be uncertain or mild corrosion risk (Mcr) if its OCCP value recorded between -276 and $-126 \mathrm{mV}$ vs SCE. Similarly, if the recorded OCCP is more negative than $-276 \mathrm{mV}$ vs SCE then the degree of the corrosion risk should be high (Hcr), i.e., more than $90 \%$ corroded the reinforcing concrete slabs at the time of measurement according to the ASTM standard [48], as summarized in Table 1.

\subsection{Phytochemical screening and FTIR analysis}

To know the constituents of secondary metabolites present in the prepared methanol extracts of both plants leaves quantitatively, the phytochemical screening of leaves extracts of both $V$. negundo and $C$. roseus plants 
were carried out using the test methods as described elsewhere [50]. In addition, functional groups present in methanol extracts of $V$. negundo and $C$. roseus leaves, including the cement powder used in the study were analyzed using the recorded Fourier transform infrared (FTIR) spectra recorded in the range of $4000-400 \mathrm{~cm}^{-1}$ using IRPrestige-21 spectrometer (Shimadzu, Japan).

Table 1. OCCP value and corrosion level of reinforced steel.

\begin{tabular}{|c|l|}
\hline $\begin{array}{c}\text { OCCP }(\mathrm{mV} \\
\text { vs SCE) }\end{array}$ & $\begin{array}{l}\text { Corrosion level of rebar steel in } \\
\text { concrete slab }\end{array}$ \\
\hline$<-276$ & $\begin{array}{l}- \text { High corrosion risk (Hcr); i.e., more } \\
\text { than 90\% probability of corrosion risk }\end{array}$ \\
\hline-276 to -126 & $\begin{array}{l}- \text { Mild corrosion risk (Mcr); i.e., } \\
\text { corrosion risk level uncertain }\end{array}$ \\
\hline$>-126$ & $\begin{array}{l}- \text { Low corrosion risk (Lcr); i.e., more } \\
\text { than 90\% probability of corrosion risk }\end{array}$ \\
\hline
\end{tabular}

\section{Results and discussion}

\subsection{Characterization of extracts and cement}

From the phytochemical screening test, major chemical compounds present in the methanolic extracts of the $V$. negundo and $C$. roseus leaves contain phenols, alkaloids, saponin, flavonoids, glycosides, and tannins (Table 2), which may help to form a corrosion-resistant passive film on the surface of rebars steel in concrete. The results of the phytochemical screening tests of the present work are in agreement with the previously reported data in the methanol extract of $V$. negundo [52, 53], and C. roseus [54] leaves.

Table 2. Phytoconstituents in V. negundo and C. roseus leaves extracts.

\begin{tabular}{|l|l|c|c|}
\hline Constituent & \multicolumn{1}{|c|}{$\begin{array}{c}\text { Test } \\
\text { name/agent }\end{array}$} & V. negundo & C. roseus \\
\hline Phenols & Lead acetate & + & + \\
\hline Alkaloids & Dragendroffs & + & + \\
\hline Saponins & Foam & + & + \\
\hline Flavonoids & Alkaline & + & + \\
\hline Glycosides & Legal's & + & + \\
\hline Tannins & FeCl $_{3}$ & + & + \\
\hline Terpenoids & Salkowski & - & - \\
\hline
\end{tabular}

$+=$ presence , and $-=$ absence of phytoconstituents

FTIR analysis makes it possible to find out the functional groups present in the materials like plant extracts and cement powder. Figures 3(a) and 3(b) show the IR spectra recorded, respectively, for methanol extracts of $V$. negundo and $C$. roseus plants, and cement powder, as summarized in Table 3 . The symmetric and broad absorption peak at $3320 \mathrm{~cm}^{-1}$ (V. negundo), and $3288 \mathrm{~cm}^{-1}$ (C. roseus) attributes for $\mathrm{O}-\mathrm{H}$ (stretch) of hydroxyl compounds. The asymmetric and symmetric stretching of $\mathrm{C}-\mathrm{H}$ vibrations of the methanolic extracts of both plants ascribe by the peaks around $2926 \mathrm{~cm}^{-1}$ and $2850 \mathrm{~cm}^{-1}$, respectively, as shown in Fig. 3(a). Similarly, $\mathrm{C} \equiv \mathrm{N}$ (stretch) or P-H bonding in the vicinity $2376-2327 \mathrm{~cm}^{-1}$ noted in the methanolic extracts of both plants.
Table 3. FTIR band of the Vitex negundo and Catharanthus roseus extract.

\begin{tabular}{|c|c|l|}
\hline \multicolumn{2}{|l|}{ Wavenumber $\left(\mathbf{c m}^{-\mathbf{1}}\right)$} & \multicolumn{2}{|c|}{ Assignements } \\
\hline V. negundo & C. roseus & \multicolumn{1}{|c|}{$\begin{array}{l}\text { O-H stretching due to } \\
\text { hydrogen bonding }\end{array}$} \\
\hline 3320 & 3288 C-H) \\
\hline 2926 & 2926 & $\begin{array}{l}\text { Methylene } \\
\text { asymmetrical stretching }\end{array}$ \\
\hline 2854 & 2850 & $\begin{array}{l}\text { Methyl (C-H) symmetrical } \\
\text { stretching }\end{array}$ \\
\hline $2376-2327$ & $2376-$ & $\begin{array}{l}\text { C=N stretching or P-H } \\
\text { bonding }\end{array}$ \\
\hline 1692 & - & $\begin{array}{l}\text { C=O stretching (lowe value } \\
\text { may be conjugated with other } \\
\text { groups) }\end{array}$ \\
\hline 1608,1515 & - & C-C ring stretching \\
\hline- & 1572 & C-C ring stretching \\
\hline 1448 & 1448 & C-O-H in-plane bending \\
\hline 1370 & 1383 & C-H bending \\
\hline 1268 & 1256 & C-O bending \\
\hline 1165 & - & P=O stretching \\
\hline 1028 & 1028 & O-H bending \\
\hline 925 & 925 & O-H bending \\
\hline 852 & 852 & C-H (para-benzene) \\
\hline 816 & 816 & C-H bending \\
\hline 780 & 780 & C-H (meta-benzene) \\
\hline & & \multicolumn{2}{|l|}{} \\
\hline
\end{tabular}
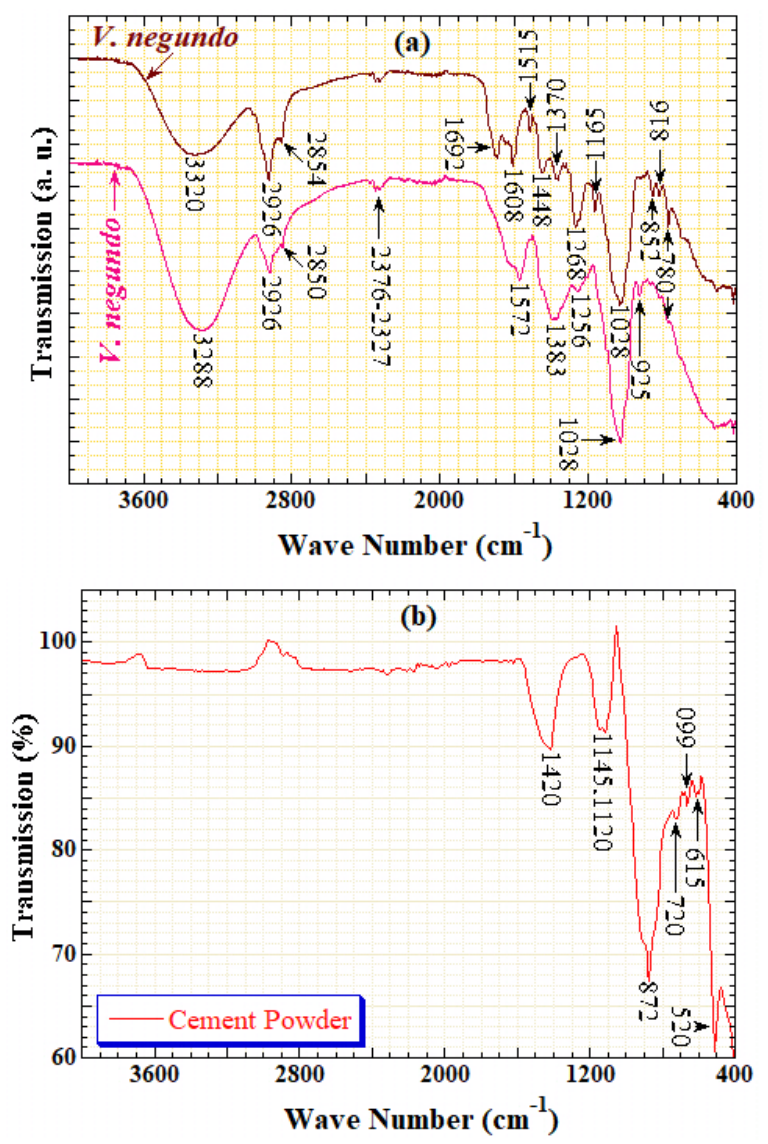

Fig. 3. FTIR spectra of the (a) methanol extracts of $V$. negundo and $C$. roseus leaves, and (b) OPC cement powder.

Besides, the $\mathrm{C}=\mathrm{O}$ (carboxylic acid) group for $V$. negundo extract indicated by the presence of IR peaks at $1692 \mathrm{~cm}^{-1}, 1608 \mathrm{~cm}^{-1}, 1448 \mathrm{~cm}^{-1}$, and of the C-O group at $1268 \mathrm{~cm}^{-1}$, which are less pronounced in spectra of $C$. 
roseus extract. The results of FTIR analysis of both plant extracts are in full agreement with the phytochemical screening tests as explained aforementioned, and also confirmed the presence of phenol, alkane, alkene, carboxylic acid, aromatic, nitro compounds including alcohol, and benzene, which is also in agreement with previously reported data $[55,56]$. On the other hand, Fig. 3(b) shows the IR spectra of the cement powder used for preparing the reinforcement concrete slabs to accomplish this work.

It notice that IR peaks around $3200-3500 \mathrm{~cm}^{-1}$ and $1620-1640 \mathrm{~cm}^{-1}$ do not appear, which disclosed that the cement used for the study was free of (bulk) water or nearly dehydrated powder [57]. The appearance of absorption peak around $1145-1120 \mathrm{~cm}^{-1}$ wave number regions revealed that the cement sample contained remarkable amounts of carbonates and silicates. The FTIR absorption peaks at $1420 \mathrm{~cm}^{-1}$ and $872 \mathrm{~cm}^{-1}$ assigned to the $\mathrm{C}-\mathrm{O}$ stretching and $\mathrm{C}-\mathrm{O}$ bending, respectively, of the $\mathrm{CO}_{3}{ }^{2-}$ ions present in the cement powder [58]. Especially, a strong absorption band exhibited between $1000-800 \mathrm{~cm}^{-1}$ with a peak value at about $872 \mathrm{~cm}^{-1}$ revealed that the cement powder contains the $\mathrm{C}_{2} \mathrm{~S}$ phase calcium silicate. The peak at 520 $\mathrm{cm}^{-1}$ assigned for bending vibration of O-Si-O bonds within the tetrahedral $\mathrm{SiO}_{4}$ groups present in the cement sample [59].

\subsection{Plant extracts as rebar corrosion inhibitor}

The efficacy of different concentrations (i.e., 500, 1000, 2000, and $4000 \mathrm{ppm}$ ) of methanol extracts of Vitex negundo, and Catharanthus roseus plants leaves were studied for viewing their corrosion inhibiting actions on the reinforcement steel rebars in concrete slabs at ambient laboratory conditions using half-cell corrosion potential (HCCP) method following the ASTM standard [48]. For the present study completion, changes of opencircuit corrosion potential (OCCP) of a total of nine steel-reinforced concrete slabs without and with four different concentrations of two plant extracts (separately) were recorded at the different time interval between 7 to 150 days. Figures 4 (a) and 4(b) show the changes of the recorded OCCP values of the reinforced rebars from eight points marked on the surface of the concrete slab (see Fig. 1), which was prepared without the addition of the plant extract. All the recorded OCCPs are also given in Table 4

The OCCP values of all eight points are more noble regions than $-125 \mathrm{mV}$ vs $\mathrm{SCE}$ up to the first seven weeks, as depicted in Fig. 4(a), which suggests that there was a low corrosion risk (less than $10 \%$ probability of corrosion risk) during this period based on the ASTM C876-91 standard [48]. Nevertheless, with increasing the exposure time between 49-150 days, all the OCCP values are in the range of $-126 \mathrm{mV}$ to $-275 \mathrm{mV}$ vs SCE, suggesting the high probability of the corrosion risk of the reinforced steel rebars in the concrete slab without plant extract addition. Moreover, Fig. 4(b) represents the mean OCCP values with error bar as a function of exposure times of the concrete slabs, which inferred that the mean OCCP values shifted to corrosive regions with exposure times. The standard deviation from the mean OCCP values for each interval time found between 10 to $36 \mathrm{mV}$, as summarized in Table 4, and depicted in Fig. 4(b). The results indicate that the localized types of corrosion could expect to the steel rebar in the concrete slab without the addition of plant extract. However, the OCCP of the steel rebars of all the concrete slabs is remarkably shifted to a more noble direction than the value of $-125 \mathrm{mV}$ (SCE) with the additions of 500-4000 ppm of each of both plant extracts, as summarized in Table 4.
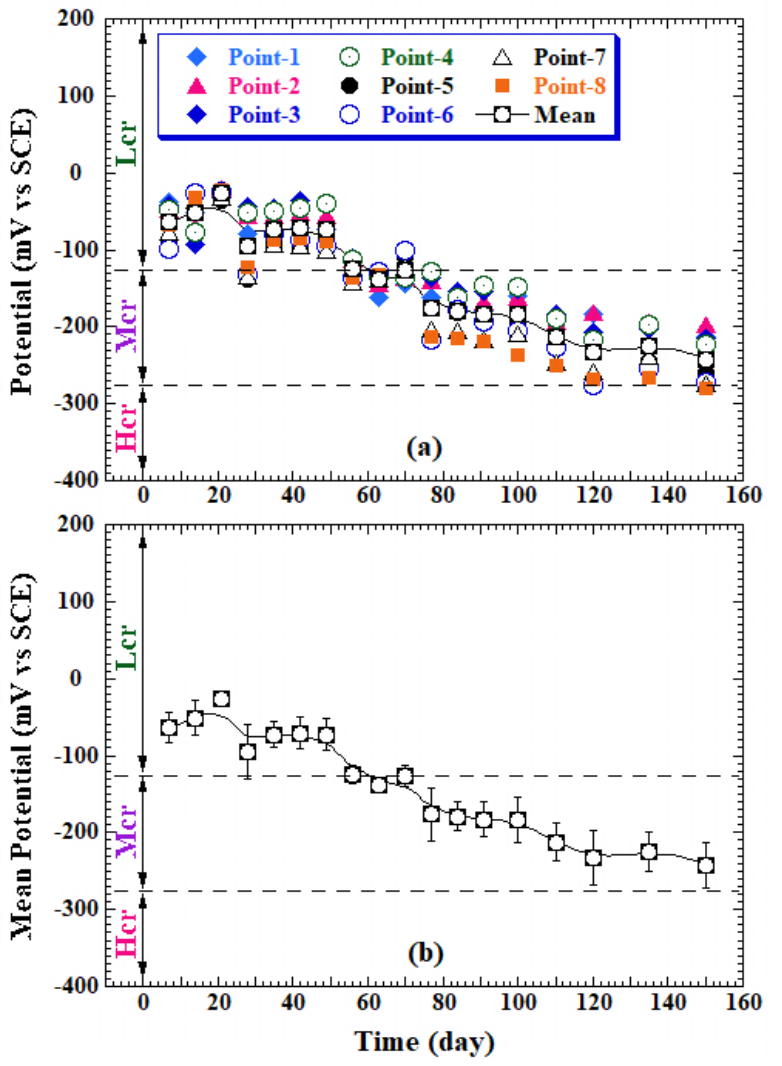

Fig. 4. Changes in the (a) OCCP values of all eight points, and (b) mean OCCP with the error bar of the steel rebar in concrete slab without plant extract.

Figures 5(a) and 5(b), respectively, display the potency of different concentrations of Vitex negundo and Catharanthus roseus extracts for the corrosion inhibition actions on the steel rebars in concrete. Most of all the mean OCCP values of all concrete slabs with plant extracts fluctuated inconsistently up to 4-6 weeks, and after then it attained a steady state, as shown in Fig. 5. Such behavior of the initial variations of the OCCP value is mainly due to the formation of unstable films on the rebar surface at initial concrete setting periods, and the time required for the occurrence of a stable and diffusion barrier passive film. Besides, the mean OCCP values of all the steel rebars in concrete slabs with plant extract additions significantly shifted to the Lcr region with more positive potential values than $-126 \mathrm{mV}$ (SCE), especially after 6-7 weeks exposure times. 
Table 4. Mean OCCP and standard deviation values of different steel reinforced concrete slabs with and without plant extracts.

\begin{tabular}{|c|c|c|c|c|c|c|c|c|c|c|c|c|c|c|}
\hline \multirow{4}{*}{$\begin{array}{l}\text { Time } \\
\text { (day) }\end{array}$} & \multicolumn{14}{|c|}{ ОССР ( $\mathrm{mV}$ vs SCE) } \\
\hline & \multirow{2}{*}{\multicolumn{2}{|c|}{$\begin{array}{l}\text { Without } \\
\text { extract }\end{array}$}} & \multicolumn{6}{|c|}{ Conc. of $V$. negundo extract in concrete (ppm) } & \multicolumn{6}{|c|}{ Conc. of C. roseus extract in concrete (ppm) } \\
\hline & & & \multicolumn{2}{|c|}{1000} & \multicolumn{2}{|c|}{2000} & \multicolumn{2}{|c|}{4000} & \multicolumn{2}{|c|}{1000} & \multicolumn{2}{|c|}{2000} & \multicolumn{2}{|l|}{4000} \\
\hline & $\overline{\mathrm{x}}$ & SD* & $\overline{\mathrm{x}}$ & SD* & $\overline{\mathrm{x}}$ & SD* & $\overline{\mathrm{x}}$ & SD* & $\overline{\mathrm{x}}$ & SD* & $\overline{\mathrm{x}}$ & SD* & $\overline{\mathrm{x}}$ & SD* \\
\hline 7 & -63 & \pm 20.1 & -61 & \pm 26.0 & -110 & \pm 6.8 & -113 & \pm 15.1 & -116 & \pm 13.4 & -109 & \pm 9.3 & -59 & \pm 25.1 \\
\hline 14 & -52 & \pm 22.6 & -120 & \pm 8.7 & -30 & \pm 4.1 & -45 & \pm 12.9 & -27 & \pm 5.0 & -32 & \pm 11.9 & -37 & \pm 6.9 \\
\hline 21 & -27 & \pm 4.9 & -116 & \pm 9.4 & -51 & \pm 8.7 & -63 & \pm 18.7 & -55 & \pm 8.3 & -28 & \pm 15.4 & -34 & \pm 9.4 \\
\hline 28 & -95 & \pm 36.2 & -121 & \pm 19.7 & -113 & \pm 4.8 & -151 & \pm 17.5 & -149 & \pm 16.0 & -75 & \pm 6.5 & -129 & \pm 17.4 \\
\hline 35 & -73 & \pm 17.1 & -108 & \pm 15.5 & -98 & \pm 5.1 & -148 & \pm 17.6 & -122 & \pm 13.4 & -64 & \pm 8.2 & -89 & \pm 11.3 \\
\hline 42 & -71 & \pm 20.9 & -82 & \pm 16.3 & -96 & \pm 5.5 & -125 & \pm 18.9 & -90 & \pm 7.8 & -55 & \pm 5.2 & -96 & \pm 12.3 \\
\hline 49 & -73 & \pm 21.4 & -68 & \pm 9.4 & -92 & \pm 13.3 & -115 & \pm 17.4 & -87 & \pm 10.1 & -65 & \pm 6.9 & -86 & \pm 15.3 \\
\hline 56 & -124 & \pm 11.6 & -54 & \pm 7.2 & -31 & \pm 3.9 & -60 & \pm 18.3 & -50 & \pm 12.8 & -21 & \pm 6.1 & -73 & \pm 28.5 \\
\hline 63 & -138 & \pm 10.1 & -50 & \pm 7.6 & -71 & \pm 4.1 & -87 & \pm 9.0 & -95 & \pm 10.2 & -75 & \pm 15.6 & -94 & \pm 16.1 \\
\hline 70 & -127 & \pm 13.5 & -51 & \pm 9.7 & -72 & \pm 20.9 & -84 & \pm 8.2 & -102 & \pm 12.4 & -74 & \pm 17.6 & -78 & \pm 16.3 \\
\hline 77 & -176 & \pm 34.0 & -48 & \pm 6.5 & -63 & \pm 9.2 & -63 & \pm 11.8 & -77 & \pm 9.5 & -56 & \pm 13.6 & -63 & \pm 9.5 \\
\hline 84 & -179 & \pm 18.6 & -51 & \pm 9.2 & -50 & \pm 10.8 & -64 & \pm 7.7 & -84 & \pm 6.8 & -102 & \pm 14.3 & -75 & \pm 12.3 \\
\hline 91 & -183 & \pm 23.3 & -52 & \pm 9.1 & -63 & \pm 10.2 & -71 & \pm 12.7 & -87 & \pm 8.3 & -76 & \pm 9.8 & -89 & \pm 7.7 \\
\hline 100 & -183 & \pm 28.7 & -51 & \pm 10.2 & -63 & \pm 10.9 & -72 & \pm 16.8 & -89 & \pm 9.6 & -83 & \pm 9.0 & -87 & \pm 13.6 \\
\hline 110 & -212 & \pm 23.7 & -37 & \pm 9.0 & -73 & \pm 12.2 & -55 & \pm 14.2 & -95 & \pm 4.3 & -74 & \pm 8.1 & -79 & \pm 10.5 \\
\hline 120 & -233 & \pm 35.5 & -36 & \pm 6.8 & -81 & \pm 13.1 & -78 & \pm 10.8 & -92 & \pm 12.8 & -89 & \pm 9.4 & -93 & \pm 9.8 \\
\hline 135 & -225 & \pm 25.4 & -53 & \pm 6.6 & -93 & \pm 8.3 & -91 & \pm 9.1 & -88 & \pm 9.9 & -79 & \pm 5.5 & -84 & \pm 6.4 \\
\hline 150 & -242 & \pm 29.4 & -49 & \pm 13.5 & -87 & \pm 11.3 & -87 & \pm 11.2 & $\begin{array}{l}-103 \\
\end{array}$ & \pm 18.8 & -116 & \pm 8.7 & -99 & \pm 12.4 \\
\hline
\end{tabular}
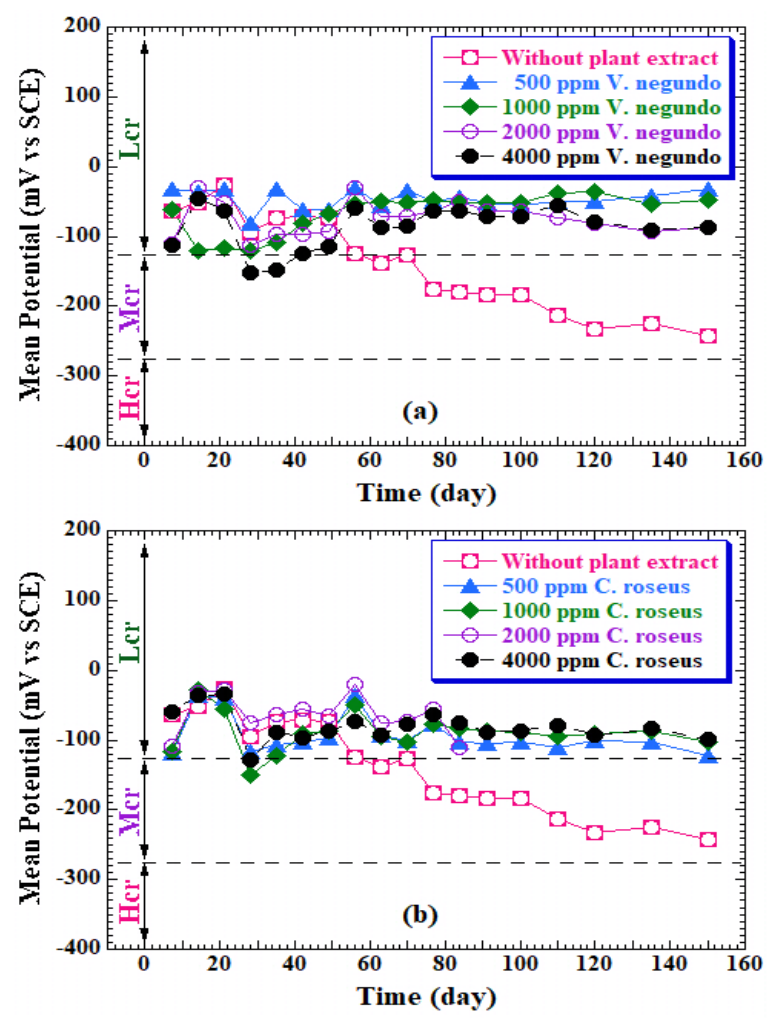

Fig. 5. Changes in the mean OCCP values of the steel rebar in concrete slab with different concentrations of (a) Vitex negundo, and (b) Catharanthus roseus extracts.

Correspondingly, Fig. 5(a) exhibits that the additions of $500 \mathrm{ppm}$ and $1000 \mathrm{ppm}$ Vitex negundo plant extract in the reinforced concrete seem to more effective in mitigating and controlling the corrosion of the steel rebars in concrete structures as compared with the concrete slabs with 2000 and 4000 ppm. However, the effectiveness of the anti-corrosion behavior of the
Catharanthus roseus plant extract increased with increasing its concentration up to $4000 \mathrm{ppm}$. Mainly, the addition of $2000 \mathrm{ppm}$ and 4000 ppm Catharanthus roseus extracts proved to be more effective in shifting the mean OCCP to the Lcr region where it assumes for occurring less than $10 \%$ possibility of the steel rebars corrosion in concrete slabs based on the ASTM C876-15 standard [48].

A comparative study of the efficacy of the different concentrations of the green-based two plants extracts and one locally used synthetic waterproofing agent was checked over for controlling or minimizing the corrosion degree of steel rebars in concrete slabs, and the results are displayed in Fig. 6. The concrete slabs with the additions of 500 and $1000 \mathrm{ppm}$ Vitex negundo extract exhibited a higher corrosion inhibition action than of Catharanthus roseus extract in the corresponding concentrations by shifting the OCCP values towards a more positive direction, i.e., in the areas of less than 10 $\%$ probability of corrosion rate, as shown in Figs. 6(a) and 6(b).

However, Figs. 6(c) and 6(d) show that both the plants' extracts have the same degree of corrosion inhibiting actions to the steel rebars in concrete slabs at 1000, 2000, and $4000 \mathrm{ppm}$ concentrations, which is a slightly lower inhibiting level than by $500-1000$ ppm Vitex negundo, and slightly higher inhibiting actions than of 500 ppm Catharanthus roseus extract. Such result is in agreement with the previously reported works that anti-corrosion properties of the methanolic extract of Vitex negundo leaves to mild steel in biofuels reported higher than of the Catharanthus roseus extract due to the formation of stable and diffusion-barrier passive film from the potentiodynamic measurements [36]. 

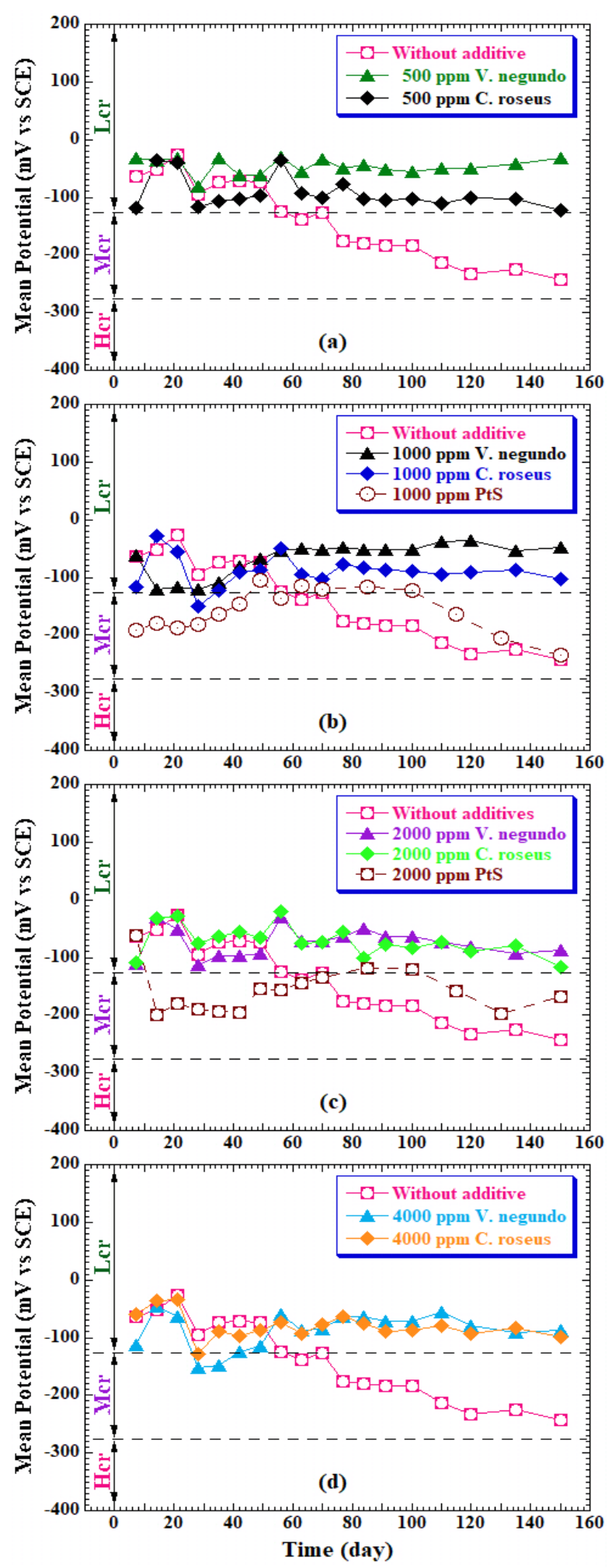

Fig. 6. The effects of (a) 500 ppm, (b) 1000 ppm, 2000 ppm, and $4000 \mathrm{ppm}$ concentrations of the $V$. negundo and $C$. roseus plant extracts, and PtS waterproofing chemical in the concrete slab.

Such high anti-corrosion effect to the steel rebars in concrete slabs by low concentrations (i.e., $500 \& 1000$ ppm) of the Vitex negundo extract compared with the Catharanthus roseus extract could be accredited to have high amounts of phytoconstituents in the Vitex negundo extract than Catharanthus roseus extract. The high amounts of N-, S-, O-containing aromatic and $\pi$ electronrich compounds, which have higher basicity and electron density, are responsible for the formation of a protected diffusion-barrier passive film on the rebar surface by adsorption mechanism that isolates the steel rebars from the corrosive concrete environment [60, 61]. Apart from such causes, aromatic ring containing compounds with oxygen reported to be zone of corrosion inhibition [62]. Despite the fact, both the plant extracts have good anticorrosion properties in all concentrations of 500-4000 ppm and thence could apply as green concrete additives to increase the corrosion resistance of the steel rebar. However, the anti-corrosion performance of the locally practiced waterproofing synthetic chemical, named PtS showed remarkably lower than the additions of plant extracts at the same concentrations, as displayed in Figs. $6(b)$ and $b(c)$, based on the shifting of corrosion potential $(\phi$ corr. $)$ values to a more positive direction than $-126 \mathrm{mV}$ (SCE).

\section{Conclusion}

The leaf extracts of Vitex negundo and Catharanthus roseus plants used in this study acted as a green-based corrosion inhibitor to increase the corrosion resistance properties of the reinforced steel rebars in concrete slabs. The plant extracts have sufficient anti-corrosion properties for the reinforced rebars, which is presumably due to the presence of abundant amounts of hetero-atoms and aromatic ring compounds as the major phytoconstituents in these two plant extracts.

The efficacious corrosion inhibiting the action of the methanolic extracts of $V$. negundo leaves to the reinforced steel rebars in concrete is especially found to be more effective green-based corrosion inhibitors than the Catharanthus roseus extracts at the concentrations of 500-1000 ppm. The present research work explored first time the beneficial uses of different green-based concrete additives obtained from Nepal origin Vitex negundo and Catharanthus roseus plants extract for controlling the steel corrosion mechanism in different types of concrete infrastructures.

\section{Acknowledgment}

The University Grants Commission-Nepal, Sanothimi, Bhaktapur of Nepal is highly acknowledged for providing the UGC Master Research Support (MRS-76/77-S\&T-22) to AG for conducting this research work.

\section{References}

1. J.P. Broomfield, Corrosion of steel in concrete: understanding, investigation, and repair ( $2^{\text {nd }}$ edition, CRC Press, Taylor \& Francis Group, London, p. 296, 2019)

2. W. Green, F. Collins, M. Forsyth, Up to date overview of aspects of steel reinforcement corrosion in concrete. In Brian Cherry paper series (The Australasian Corrosion Association Inc., 2020) 
3. ISO/TC 071, Strategic business plan (ISO Technical Committee, p. 11, 2016)

4. C.R. Gagg, Cement and concrete as an engineering material: An historic appraisal and case study analysis, Engineering Failure Analysis, 40, (2014): $114-140$

5. U.M. Angst, Challenges and opportunities in corrosion of steel in concrete, Materials and Structures, 51, (2018): 4

6. R.W. Revie, H.H. Uhlig, Corrosion and corrosion control: An introduction to corrosion science and engineering ( $4^{\text {th }}$ edition, John Wiley and Sons, Inc., Hoboken New Jersey, USA, p. 490, 2008)

7. J. Bhattarai, Frontiers of corrosion science $\left(1^{\text {st }}\right.$ edition, Kshitiz Publication, Kirtipur, Kathmandu, Nepal, p. 304, 2010)

8. B. Cherry, W. Green, Corrosion and protection of reinforced concrete $\left(1^{\text {st }}\right.$ edition, CRC Press, Taylor \& Francis Group, p. 402, 2021)

9. J.O'M. Bockris, A.K.N. Reddy, Modern electrochemistry: Electrodics in chemistry, engineering, biology, and environmental science $\left(2^{\text {nd }}\right.$ edition, volume 2B, Kluwer Academic/Plenum Publisher, New York, 2001)

10. NPL, The corrosion of steel in concrete- Basic understanding, monitoring and corrosion control methods (National Physical Laboratory, NPL Management Ltd., Middlesex, UK, p. 11, 2020)

11. S.A. Asipita, M. Ismail, M.Z.A. Majid, Z.A. Majid, C. Abdullah, J. Mirza, Green Bambusa arundinacea leaves extract as a sustainable corrosion inhibitor in steel-reinforced concrete, Journal of Cleaner Production, 67, (2014): 139-146

12. C. Apostolopoulos, K. Koulouris, Corrosion effect on bond loss between steel and concrete (IntechOpen, p. $18,2020)$

13.E.C. Seyhan, F. Goodwin, I.-W. Huang, Corrosion protection of steel reinforcement by using surface applied corrosion inhibitors, MATEC Web Conference, 289, (2019): 05001

14. K. Doi, S. Hiromoto, T. Shinohara, K. Tsuchiya, H. Katayama, E. Akiyama, Role of mill scale on corrosion behavior of steel rebars in mortar, Corrosion Science, 177, (2020): 108995

15. R. Cantone, M. Fernández Ruiz, A. Muttoni, A detailed view on the rebar-to-concrete interaction based on refined measurement techniques, Engineering Structures, 226, (2021): 111332

16. J.O. Okeniyi, J.O. Ikotun, E.T. Akinlabi, E.T. Okeniyi, Anticorrosion behaviour of Rhizophora mangles L. bark-extract on concrete steel-rebar in saline/marine simulating-environment, The Scientific World Journal, 2019, (2019): 6894714

17. J.O. Okeniyi, E.T. Akinlabi, J.O. Ikotun, S.A. Akinlabi, E.T. Okeniyi, O.M. Elizabeth, Rhizophora mangle L. leaf biochemical characterization: Natural green total corrosion inhibition prospect on concrete steel-reinforcement in $3.5 \% \mathrm{NaCl}$, Jurnal Teknologi (Sciences \& Engineering), 81, 1 (2019): 11-21

18. J.O. Okeniyi, C. Loto, A. Popoola, Effects of Phyllanthus muellerianus leaf-extract on steelreinforcement corrosion in $3.5 \% \mathrm{NaCl}$-immersed concrete, Metals, 6, 11 (2016): 255

19. Y.P. Asmara, T. Kurniawan, A.G.E. Sutjipto, J. Jamiluddin Jafar, Application of plants extracts as green corrosion inhibitors for steel in concrete- a review, Indonesian Journal of Science \& Technology, 3, 2 (2018): 158-170

20. D.B. Left, M. Zertoubi, S. Khoudali, M. Azzi, New application of Chamaerops humilis L. extract as a green corrosion inhibitor for reinforcement steel in a simulated carbonated concrete pore solution, Portugaliae Electrochimica Acta, 36, 4 (2018): 249257

21. M. Ben Harb, S. Abubshait, N. Etteyeb, M. Kamoun, A. Dhouib, Olive leaf extract as a green corrosion inhibitor of reinforced concrete contaminated with seawater, Arabian Journal of Chemistry, 13, 3 (2020): 4846-4856

22. M. Zhang, Davidian involucrata leaves extract as green corrosion inhibitor for low carbon steel in concrete pore solution containing chloride ions, International Journal of Electrochemical Science, 16, (2021): 21042

23. G. Xie, L. Wei, Inhibitor effect of Anthocleista djalonensis extract on the corrosion of concrete steel reinforcement, International Journal of Electrochemical Science, 13, (2018): 5311-5322.

24. V.S. Helbert, L. Gaillet, T. Chaussadent, V. Gaudefroy, J. Creus, Rhamnolipids as an eco-friendly corrosion inhibitor of rebars in simulated concrete pore solution: Evaluation of conditioning and addition methods, Corrosion Engineering, Science and Technology, 55, 2 (2020): 91-102

25. R. Anitha, S. Chitra, V. Hemapriya, I.M. Chung, S.H. Kim, M. Prabakaran, Implications of eco-addition inhibitor to mitigate corrosion in reinforced steel embedded in concrete, Construction and Building Materials, 213, (2019): 246-256

26.C.A. Loto, O.O. Joseph, R.T. LotoA.P.I. Popoola, Inhibition effect of Vernonia amygdalina extract on the corrosion of mild steel reinforcement in concrete in $3.5 \mathrm{M} \mathrm{NaCl}$ environment, International Journal of Electrochemical Science, 8, 9 (2013): 11087-11100

27. R.A. Limco, H.P. Bacosa, A.A. Lubguban, J.S. Buluran, Morinda citrifolia (Noni) leaf extract as corrosion inhibitor for steel-reinforced concrete in saline environment, International Journal of Environmental Science and Technology, 17, (2020): 4531-4540

28. J.A. Selvi, M. Arthanareeswari, T. Pushpamalini, S. Rajendran, T. Vignesh, Effectiveness of Vinca rosea leaf extract as corrosion inhibitor for mild steel in 1 $\mathrm{N} \mathrm{HCl}$ medium investigated by adsorption and electrochemical studies, International Journal of 
Corrosion and Scale Inhibition, 9, 4 (2020): 14291443

29. R.M.A. Shahba, A.E.E. Fouda, A.E. El-Shenawy, A.S.M. Osman, Effect of Catharanthus roseus (Vince rosea) and turmeric (Curcuma longa) extracts as green corrosion inhibitors for mild steel in $1 \mathrm{M}$ $\mathrm{HCl}$, Materials Sciences and Applications, 7, (2016): 654-671

30. K. Hema, B.R. Venkatraman, A. Subramania, Aqueous extract of Vitex negundo leaves as green corrosion inhibitor for the protection of carbon steel in $1 \mathrm{~N} \mathrm{HCl}$ solution, Journal of Environmental Nanotechnology, 4, 3 (2013): 42-50

31. N. Palaniappan, I. Cole, F. Caballero-Briones, S. Manickam, K.R. Justin Thomas, D. Santos, Experimental and DFT studies on the ultrasonic energy-assisted extraction of the phytochemicals of Catharanthus roseus as green corrosion inhibitors for mild steel in $\mathrm{NaCl}$ medium, RSC Advances, 10, (2020): 5399-5411

32. M. Rana, S. Joshi, J. Bhattarai, Extract of different plants of Nepalese origin as a green corrosion inhibitor for mild steel in $0.5 \mathrm{M} \mathrm{NaCl}$ solution, Asian Journal of Chemistry, 29, 5 (2017): 1130-1134

33. Savita, P. Mourya, N. Chaubedi, V.K. Singh, M.M. Singh, Eco-friendly inhibitors for copper corrosion in nitric acid: Experimental and theoretical evaluation, Metallurgical and Materials Transactions B, 47, 1 (2016): 47-57

34. S. Sirajunnisa, M.I. Fazal Mohamed, A. Subramania, Vitex negundo leaves extract as green inhibitor for the corrosion of aluminium $1 \mathrm{~N} \mathrm{NaOH}$ solution, Journal of Chemical and Pharmaceutical Research, 6, (2014): 580-588

35. B.N. Subedi, K. Amgain, S. Joshi, J. Bhattarai, Green approach to corrosion inhibition effect of Vitex negundo leaf extract on aluminium and copper metals in biodiesel and its blend, International Journal of Corrosion and Scale Inhibition, 8, 3 (2019): 744-759 (2019)

36.P. Katuwal, R. Regmi, S. Joshi, J. Bhattarai, Assessment on the effective green-based Nepal origin plants extract as corrosion inhibitor for mild steel in bioethanol and its blend, European Journal of Advanced Chemistry Research, 1, 5 (2020): 1-13

37. N.R. Phulara, J. Bhattarai, Assessment on corrosion damage of steel reinforced concrete structures of Kathmandu Valley using corrosion potential mapping method, Journal of the Institute of Engineering, 15, 2 (2019): 47-56

38. I. Laudari, N.R. Phulara, M. Gautam, J. Bhattarai, Evaluation on the corrosion condition of some steelreinforced concrete infrastructures available in Pokhara valley of Nepal, Tribhuvan University Journal, (2021): in press

39. J. Bhattarai, D. Paudyal, K. P. Dahal, Study on the soil corrosivity towards the buried-metallic pipes in Kathmandu and Chitwan valley of Nepal. In Proceedings of the 17th Asian-Pacific Corrosion
Control Conference (Paper No. 17039, 27-30 January, 2016, IIT Bombay, India, p. 12)

40.P.P. Bhandari, K.P. Dahal, J. Bhattarai, The Corrosivity of soil collected from Araniko Highway and Sanothimi areas of Bhaktapur, Journal of Institute of Science and Technology, 18, 1 (2013): 71-77

41. K.P. Dahal, J.N. Timilsena, M. Gautam, J. Bhattarai, Investigation on probabilistic model for corrosion failure level of buried-pipelines in Kirtipur urban areas (Nepal), Journal of Failure Analysis and Prevention, 21, 3 (2021): 914-926

42. K.P. Dahal, R.K. Karki, J. Bhattarai, Evaluation of corrosivity of soil collected from the central part of Kathmandu Metropolis (Nepal) to water supply metallic pipes, Asian Journal of Chemistry, 30, 7 (2018): 1525-1530

43. Y.P. Dhakal, K.P. Dahal, J. Bhattarai, Investigation on the soil corrosivity towards the buried water supply pipelines in Kamerotar Town Planning areas of Bhaktapur, Nepal, Bibechana, 10, (2014): 82-91

44. A. Poudel, K.P. Dahal, J. Bhattarai, A classification approach for corrosion rating of soil to buried water pipelines: A case study in BudhanilkanthaMaharajganj roadway areas of Nepal, World Journal of Applied Chemistry, 5, 3 (2020): 47-56 (2020)

45. S.K. Regmi, K.P. Dahal, J. Bhattarai, Soil corrosivity to the buried-pipes used in Lalitpur, Kathmandu Valley, Nepal, Nepal Journal of Environmental Science, 3, 1 (2015): 15-20

46. J. Bhattarai, An overview on the non-destructive indepth surface analysis of corrosion-resistant films: A case study of $\mathrm{W}$-xCr deposits in $12 \mathrm{M} \mathrm{HCl}$ solution, Bibechana, 18, 1 (2021): 201-213

47. J. Bhattarai, Review on in-depth analysis of the passive films of W-xTi alloys by angle-resolved Xray photoelectron spectroscopy, Science Journal of Chemistry, 8, 2 (2020): 28-35

48. ASTM C876-15, Standard test method for corrosion potentials of uncoated reinforcing steel in concrete (ASTM International, West Conshohocken, PA, USA, p. 8, 2015)

49. ASTM C1582 / C1582M-11, Standard specification for admixtures to inhibit chloride-induced corrosion of reinforcing steel in concrete (ASTM International, West Conshohocken, USA, pp. 10, 2017)

50. T.M.B. Bandiola, Extraction and qualitative phytochemical screening of medicinal plants: a brief summary, International Journal of Pharmacy, 8, 1 (2018): 137-143

51. A. Flores-Nicolas, M. Flores-Nicolas, J. UruchurtuChavarin, Corrosion effect on reinforced concrete with the addition of graphite powder and its evaluation on physical-electrochemical properties, Revista ALCONPAT, 11, 1 (2021): 18-33

52. N. Koirala, C. Dhakal, N.N. Munankarmi, S.W. Ali, A. Hameed, N. Martins, J. Sharifi-Rad, M. Imran, A.M. Arif, M.S. Hanif, B. Salehi, (2020). Vitex 
negundo Linn: phytochemical composition, nutritional analysis, and antioxidant and antimicrobial activity. Cellular and Molecular Biology (Noisy-le-Grand, France), 66, 4 (2020): 1-7

53. S. Saklani, A.P. Mishra, H. Chandra, M.S. Atanassova, M. Stankovic, B. Sati, M.A. Shariati, M. Nigam, M.U. Khan, S. Plygun, H. Elmsellem, H.A.R. Suleria, Comparative evaluation of polyphenol contents and antioxidant activities between ethanol extracts of Vitex negundo and Vitex trifolia L. leaves by different methods, Plants, 6, 4 (2017): 45

54. S.C. Ohadoma, H.U. Michael, Effects of coadministration of methanol leaf extract of Catharanthus roseus on the hypoglycemic activity of metformin and glibenclamide in rats, Asian Pacific Journal of Tropical Medicine, 4, 6 (2011): 475-477

55. M.K. Dwivedi, R. Shukla, N.K. Sharma, A. Manhas, K. Srivastava, N. Kumar, P.K Singh, Evaluation of ethnopharmacologically selected Vitex negundo L. for In vitro antimalarial activity and secondary metabolite profiling, Journal of Ethnopharmacology, 275, (2021): 114076

56. A. Kalaiselvi, S.M. Roopan, G. Madhumitha, C. Ramalingam, G. Elango, Synthesis and characterization of palladium nanoparticles using Catharanthus roseus leaf extract and its application in the photo-catalytic degradation, Spectrochimica Acta- Part A: Molecular and Biomolecular Spectroscopy, 135, (2015): 116-119
57. R. Ylmen, U. Jaglid, I. Panas, Monitoring early hydration of cement by ex situ and in situ ATRFTIR- a comparative study, Journal of the American Ceramic society, 97, 11 (2014): 3669-3675

58.E.V. Tararushkin, T.N. Shchelokova, V.D. Kudryavtseva, A study of strength fluctuations of Portland cement by FTIR spectroscopy, IOP Conference Series: Materials Science and Engineering, 919, (2020): 022017

59. J. Higl, D. Hinder, C. Rathgeber, B. Ramming, M. Lindén, Detailed in situ ATR-FTIR spectroscopy study of the early stages of C-S-H formation during hydration of monoclinic $\mathrm{C}_{3} \mathrm{~S}$, Cement and Concrete Research, 142, (2021): 106367

60. A.A. Al-Amiery, M.H.O. Ahmed, T.A. Abdullah, T.S. Gaaz, A.A.H. Kadhum, Electrochemical studies of novel corrosion inhibitor for mild steel in $1 \mathrm{M}$ hydrochloric acid, Results in Physics, 9, (2018): 978981

61. A. Kadhim, A.K. Al-Okbi, D.M. Jamil, A. Qussay, A.A. Al-Amiery, T.S. Gaaz, T. S., ... M.H. Nassir, Experimental and theoretical studies of benzoxazines corrosion inhibitors, Results in Physics, 7, (2017): 4013-4019

62. N.U. Shehu, U.I. Gaya, A.A. Muhammad, Influence of side chain on the inhibition of aluminium corrosion in $\mathrm{HCl}$ by $\alpha$-amino acids, Applied Science and Engineering Progress, 12, 3 (2019): 187-197 